\title{
Inheritance of the kernel flavour in almond
}

\author{
F. DICENTA \& J. E. GARCÍA \\ CEBAS (CSIC), Murcia, Spain
}

\begin{abstract}
In this study, the sweet, bitter or slightly bitter flavour of the kernel of 1969 almond trees was determined over a 2-year period; the trees are seedlings of 51 families deriving from crosses of 12 varieties of almond. It is proven that this trait is controlled by just one gene, with bitterness being due to the recessive allele. Trees with slightly bitter kernels are heterozygous forms, in which the bitter flavour is scarcely expressed due to an alteration of the total dominance system. In addition, the varieties used as parents have been classified as homozygous or heterozygous for this trait.
\end{abstract}

Keywords: amygdalin, bitterness, fruit breeding, intraspecific crosses, Prunus dulcis Miller.

\section{Introduction}

The sweet characteristic of the kernel, as opposed to the bitter one, has undoubtedly been of prime importance in the breeding of the almond tree, from the first selection processes carried out by farmers to the current research programmes. As a consequence of this constant selection, a progressive decrease in the frequency of alleles responsible for the bitter flavour in this species has taken place. Nevertheless, some varieties, which have been grown for years and are commercially viable, carry these alleles and, when combined with each other can produce seedlings with bitter kernels.

As happens in other Prunus, such as the peach or the apricot tree, the bitter flavour of the seed is due to amygdalin glucoside (McCarty et al., 1952; Chandler, 1957; Woodroof, 1967). The nearest amygdalin precursor (prunasina) is not produced in the kernel, but is transported from the mother plant, which is the one that has the bitter genotype (Frehner, et al., 1990), so that all the kernels of a tree will have either sweet or bitter kernels (Kester \& Asay, 1975; Spiegel-Roy, 1979; Grasselly \& Crossa-Raynaud, 1983).

In spite of the importance that the knowledge of the inheritance of this trait has for the breeder, few authors have paid enough attention to the question (Heppner, 1923, 1926; Spiegel-Roy \& Kochba, 1974; Grasselly \& Crossa-Raynaud, 1983).

The aim of this work is to determine the mode of inheritance of this trait, in order to improve the

Correspondence: Dr F. Dicenta, Station de Recherches Fruitières Méditerranéennes, Domaine de Saint-Paul, BP 91, 84143 Montfavet, France. efficiency of future breeding programmes, in which the bitter flavour is not usually a desired characteristic.

\section{Plant material and methodology}

The sweet, slightly bitter or bitter flavour of the kernel was determined in 1969 trees belonging to 51 families derived from the same number of crosses among 12 varieties of almond tree. All the cultivars have sweet kernels, except the Garrigues variety, which is slightly bitter, and Genco and Tuono, which occasionally present slightly bitter kernels. The families studied are shown in Table 1 as well as the number of individuals examined in each.

Flavour determination was carried out by tasting the kernels in two separate years; no differences were found from one year to the next, except for a very few seedlings, which had sweet kernels one year and were very slightly bitter in the second year but which were finally considered to have sweet kernels.

The data were analysed by goodness-of-fit $\chi^{2}$ in terms of the number of seedlings with sweet, slightly bitter and bitter kernel, in each family.

\section{Results and discussion}

The number of seedlings with sweet, slightly bitter, and bitter kernels of each family is shown in Table 1. It can be observed that the number of families and individuals is high, a fact that makes this study highly reliable.

The observation of the results shows that trees with a sweet kernel are more abundant: 94 per cent of the total number; bitter kernel trees represent only 4 per cent and slightly bitter ones 2 per cent. 
Table 1 Number $(n)$ and percentage (\%) of seedlings with sweet, bitter and slightly bitter kernels by families and total number of seedlings analysed $(N)$

\begin{tabular}{|c|c|c|c|c|c|c|c|}
\hline \multirow[b]{2}{*}{ Crosses } & \multirow[b]{2}{*}{$N$} & \multicolumn{2}{|l|}{ Sweet } & \multicolumn{2}{|c|}{ Bitter } & \multicolumn{2}{|c|}{$\begin{array}{l}\text { Slightly } \\
\text { bitter }\end{array}$} \\
\hline & & $n$ & $\%$ & $n$ & $\%$ & $n$ & $\%$ \\
\hline Ramillete $\times$ Genco & 62 & 61 & 98.4 & 0 & 0.0 & 1 & 1.6 \\
\hline Ramillete $\times$ Tuono & 123 & 122 & 99.2 & 0 & 0.0 & 1 & 0.8 \\
\hline Ramillete $\times$ Ferragnès & 50 & 50 & 100.0 & 0 & 0.0 & 0 & 0.0 \\
\hline Ramillete $\times$ Mono & 108 & 108 & 100.0 & 0 & 0.0 & 0 & 0.0 \\
\hline Garrigues $\times$ Genco & 33 & 20 & 60.6 & 7 & 21.2 & 6 & 18.2 \\
\hline Garrigues $\times$ Tuono & 50 & 34 & 68.0 & 11 & 22.0 & 5 & 10.0 \\
\hline Garrigues $\times$ Ferragnès & 53 & 52 & 98.1 & 0 & 0.0 & 1 & 1.9 \\
\hline Garrigues $\times$ Mono & 77 & 76 & 98.7 & 1 & 1.3 & 0 & 0.0 \\
\hline Atocha $\times$ Genco & 84 & 52 & 61.9 & 28 & 33.3 & 4 & 4.8 \\
\hline Atocha $\times$ Tuono & 21 & 18 & 85.7 & 3 & 14.3 & 0 & 0.0 \\
\hline Atocha $\times$ Ferragnès & 61 & 59 & 96.7 & 2 & 3.3 & 0 & 0.0 \\
\hline Atocha $\times$ Mono & 71 & 71 & 100.0 & 0 & 0.0 & 0 & 0.0 \\
\hline Peraleja $\times$ Genco & 22 & 22 & 100.0 & 0 & 0.0 & 0 & 0.0 \\
\hline Peraleja $\times$ Tuono & 61 & 61 & 100.0 & 0 & 0.0 & 0 & 0.0 \\
\hline Peraleja $\times$ Ferragnès & 36 & 36 & 100.0 & 0 & 0.0 & 0 & 0.0 \\
\hline Peraleja $\times$ Mono & 85 & 85 & 100.0 & 0 & 0.0 & 0 & 0.0 \\
\hline Del Cid $\times$ Genco & 49 & 48 & 98.0 & 0 & 0.0 & 1 & 2.0 \\
\hline Del Cid $\times$ Tuono & 19 & 18 & 94.7 & 0 & 0.0 & 1 & 5.3 \\
\hline Del Cid × Ferragnès & 33 & 33 & 100.0 & 0 & 0.0 & 0 & 0.0 \\
\hline Del Cid $\times$ Mono & 38 & 38 & 100.0 & 0 & 0.0 & 0 & 0.0 \\
\hline Genco $\times$ Ramillete & 28 & 26 & 92.9 & 0 & 0.0 & 2 & 7.1 \\
\hline Genco $\times$ Garrigues & 16 & 9 & 52.9 & 3 & 17.6 & 4 & 23.5 \\
\hline Ferragnès $\times$ Ramillete & 15 & 15 & 100.0 & 0 & 0.0 & 0 & 0.0 \\
\hline Ferragnès $\times$ Garrigues & 13 & 12 & 92.3 & 0 & 0.0 & 1 & 7.7 \\
\hline Titan $\times$ Ramillete & 39 & 39 & 100.0 & 0 & 0.0 & 0 & 0.0 \\
\hline Primorskii $\times$ Ramillete & 69 & 69 & 100.0 & 0 & 0.0 & 0 & 0.0 \\
\hline Primorskii × Garrigues & 73 & 72 & 94.7 & 0 & 0.0 & 1 & 1.3 \\
\hline Primorskii $\times$ Atocha & 70 & 70 & 100.0 & 0 & 0.0 & 0 & 0.0 \\
\hline Primorskii $\times$ Del Cid & 57 & 57 & 100.0 & 0 & 0.0 & 0 & 0.0 \\
\hline Wawona $\times$ Ramillete & 19 & 19 & 100.0 & 0 & 0.0 & 0 & 0.0 \\
\hline Wawona $\times$ Garrigues & 54 & 29 & 49.2 & 17 & 28.8 & 8 & 13.6 \\
\hline Wawona $\times$ Del Cid & 44 & 43 & 95.6 & 1 & 2.2 & 0 & 0.0 \\
\hline Genco $\times$ Tuono & 10 & 9 & 90.0 & 1 & 10.0 & 0 & 0.0 \\
\hline Genco $\times$ Ferragnès & 26 & 25 & 96.2 & 0 & 0.0 & 1 & 3.8 \\
\hline Genco $\times$ Mono & 47 & 47 & 100.0 & 0 & 0.0 & 0 & 0.0 \\
\hline Tuono $\times$ Genco & 44 & 35 & 79.5 & 9 & 20.5 & 0 & 0.0 \\
\hline Tuono $\times$ Ferragnès & 37 & 37 & 100.0 & 0 & 0.0 & 0 & 0.0 \\
\hline Ferragnès $\times$ Genco & 41 & 41 & 100.0 & 0 & 0.0 & 0 & 0.0 \\
\hline Ferragnès $\times$ Tuono & 15 & 15 & 100.0 & 0 & 0.0 & 0 & 0.0 \\
\hline Ferragnès $\times$ Mono & 26 & 26 & 100.0 & 0 & 0.0 & 0 & 0.0 \\
\hline Mono $\times$ Genco & 12 & 12 & 100.0 & 0 & 0.0 & 0 & 0.0 \\
\hline Mono × Tuono & 2 & 2 & 100.0 & 0 & 0.0 & 0 & 0.0 \\
\hline Mono $\times$ Ferragnès & 16 & 16 & 100.0 & 0 & 0.0 & 0 & 0.0 \\
\hline Titan $\times$ Ferragnès & 3 & 3 & 100.0 & 0 & 0.0 & 0 & 0.0 \\
\hline Titan $\times$ Mono & 2 & 2 & 100.0 & 0 & 0.0 & 0 & 0.0 \\
\hline Primorskii $\times$ Ferragnès & 15 & 15 & 100.0 & 0 & 0.0 & 0 & 0.0 \\
\hline Primorskii $\times$ Mono & 9 & 9 & 100.0 & 0 & 0.0 & 0 & 0.0 \\
\hline Primorskii $\times$ Titan & 15 & 15 & 100.0 & 0 & 0.0 & 0 & 0.0 \\
\hline Wawona $\times$ Ferragnès & 10 & 10 & 100.0 & 0 & 0.0 & 0 & 0.0 \\
\hline Wawona $\times$ Titan & 2 & 2 & 100.0 & 0 & 0.0 & 0 & 0.0 \\
\hline Wawona $\times$ Primorskii & 4 & 4 & 100.0 & 0 & 0.0 & 0 & 0.0 \\
\hline Total & 1969 & 1849 & 94 & 83 & 4 & 37 & 2 \\
\hline
\end{tabular}


Note that it was only in 11 families that some seedlings with bitter kernels were obtained, and that only in eight were there more than 5 per cent. Analysis of these families reveals that only five of the 12 cultivars are present: Garrigues, Atocha, Genco, Tuono and Wawona. We also observed that when these varieties were crossed, the percentage of trees with slightly bitter kernels varied between 0 and 23 per cent.

When some of these five varieties were crossed with the remainder, there were no seedlings with bitter kernels, with the exception of the Garrigues $\times$ Mono, Atocha $\times$ Ferragnès and Wawona $\times$ Del Cid families, in which the seedlings with bitter kernels were scarce $\langle 1.3$, 3.3. and 2.2 per cent, respectively). The percentage of trees with slightly bitter kernels in these families ranged between 0 and 7.7 per cent, but it must be observed that, as in the case of the bitter kernels, this resulted in one or two individuals in each. When none of these five varieties took part in the cross, 100 per cent of the individuals produced sweet kernels.

As neither of the cultivars was bitter but the characteristic appears in the progeny, we must assume that the bitter trait is recessive, a fact which agrees with the results obtained by others (Heppner, 1923, 1926; Spiegel-Roy \& Kochba, 1974; El Gharbi, 1981; Grasselly \& Crossa-Raynaud, 1983). In concordance with this fact, the two cultivars in a cross with bitter progeny must be heterozygous for this characteristic.

On the other hand, the existence of an important group of families that did not produce either bitter or slightly bitter kernels suggests that in this case, both cultivars must be homozygous for the sweet trait. In addition, when any of these was crossed with one of the five cultivars which carried the bitter trait, only four seedlings with bitter kernels apppeared ( 0.4 per cent), the presence of which might be due to experimental error. Furthermore, there was a small ratio ( 1 per cent) of trees with slightly bitter kernels.

In the light of the behaviour shown by their progeny, we can state that Garrigues, Atocha, Genco, Tuono and Wawona are heterozygous for this characteristic, while Ramillete, Peraleja, Del Cid, Ferragnès, Mono, Primorskii and Titan are dominant homozygous. Our conclusions on the genetic nature of Ferragnès and Tuono for this characteristic agree with those of other authors (El Gharbi, 1981; Grasselly \& CrossaRaynaud, 1983); the remaining varieties have not been studied so far.

Taking into account these observations, the results have been re-grouped in Table 2. If the frequencies of bitter kernel trees are observed, it is seen that a good adjustment to the expected frequencies has been obtained ( 3 sweet:1 bitter) in the segregation of a monogenic trait with total dominance of the sweet form. This ratio is excellent if the individuals with slightly bitter kernels are grouped with the sweet ones, to which they are phenotypically close (Table 3 ). This Table shows the levels of significance of chi-squared tests for the ratio 3 sweet:1 bitter in crosses of heterozygous cultivars, by families and globally. Studying each family in turn, the level of significance varied from 0.624 to 0.078 , and in the global analysis it was very close to unity; thus the results leave no doubt as to the verification of the established hypothesis.

In the remaining cases $(\mathrm{Hm} \times \mathrm{Hm}$ and $\mathrm{Hm} \times \mathrm{Ht})$, and bearing in mind that the expected frequency was 0 , the chi-square test could not be applied. Thus, the results are consistent with the hypothesis of 100 per cent sweet kernel trees.

As Heppner (1923, 1926), in spite of the high variability of his results, proposed the hypothesis of the monogenic control of this characteristic, other authors (El Gharbi, 1981; Grasselly \& Crossa-Raynaud, 1983; Vargas et al., 1983; Vargas \& Romero, 1988) have accepted it as valid, despite their results not conforming exactly and the plant material studied being not very abundant.

Only Spiegel-Roy \& Kochba (1974) rejected the hypothesis of the monofactorial inheritance and postulated the possibility of the intervention of three genes, although in later works (Spiegel-Roy \& Kochba, 1977; Spiegel-Roy, 1979; Spiegel-Roy \& Kochba, 1981) and without furnishing new data, they accepted Heppner's theory as valid.

The results of this study, obtained from a high number of plants, give a high reliability to the established hypothesis, which is fully confirmed by the corresponding statistical analysis.

Slightly bitter forms must correspond to heterozygous trees $(S s)$ and occasionally the presence of the recessive allele may produce a certain degree of bitterness, due to an alteration in the total dominance of the sweet flavour. In fact, among the heterozygous parents, we can find varieties with kernels that always show a slightly bitter flavour (Garrigues), that present it occasionally (Genco and Tuono) or completely sweet flavour (Atocha and Wawona). Although the slightly bitter flavour of Genco and Tuono has not been detected on some occasions (Godini et al., 1979), the chemical analysis shows that, in general, varieties from Apulia have higher levels of amygdalin than other varieties (Barbera et al., 1987).

We can infer that the use in breeding programmes of bitter kernel trees with some outstanding characteristic (resistance to diseases, kernel of excellent size and appearance, great vigour, etc), must not be disregarded if the other parent is sweet homozygous because it is to be expected that all the progeny will show sweet 
Table 2 Number $(n)$ and percentage (\%) of seedlings with sweet, bitter and slightly bitter kernels by groups

\begin{tabular}{|c|c|c|c|c|c|c|c|c|}
\hline \multirow{2}{*}{$\begin{array}{l}\text { Groups of } \\
\text { crosses }\end{array}$} & \multirow[b]{2}{*}{ Fam } & \multirow[b]{2}{*}{$N$} & \multicolumn{2}{|l|}{ Sweet } & \multicolumn{2}{|c|}{ Bitter } & \multicolumn{2}{|c|}{$\begin{array}{l}\text { Slightly } \\
\text { bitter }\end{array}$} \\
\hline & & & $n$ & $\%$ & $n$ & $\%$ & $n$ & $\%$ \\
\hline $\mathrm{Hm} \times \mathrm{Hm}$ & 17 & 616 & 616 & 100.0 & 0 & 0.0 & 0 & 0.0 \\
\hline $\mathrm{Hm} \times \mathrm{Ht}$ & 26 & 1041 & 1027 & 98.6 & 4 & 0.4 & 10 & 1.0 \\
\hline $\mathrm{Ht} \times \mathrm{Ht}$ & 8 & 312 & 206 & 66.0 & 79 & 25.3 & 27 & 8.7 \\
\hline
\end{tabular}

$\mathrm{Ht}=$ heterozygous, $\mathrm{Hm}=$ sweet homozygous. Fam = Number of families.

$N=$ Total number of seedlings in each group.

Table 3 Chi-squared test $\left(\chi^{2}\right)$ for expected frequency 3:1 (sweet:bitter) in crosses between heterozygous varieties. $N=$ number of observations. Observed and expected frequencies and signification level. (The seedlings with slightly bitter kernels have been included in those with sweet kernels)

\begin{tabular}{|c|c|c|c|c|c|c|c|}
\hline \multirow[b]{2}{*}{ Crosses } & \multirow[b]{2}{*}{$N$} & \multicolumn{2}{|c|}{ Observed } & \multicolumn{2}{|c|}{ Expected } & \multirow[b]{2}{*}{$\chi^{2}$} & \multirow[b]{2}{*}{ Significance } \\
\hline & & Sweet & Bitter & Sweet & Bitter & & \\
\hline Garrigues $\times$ Genco & 33 & 26 & 7 & 24.75 & 8.25 & 0.252 & 0.615 \\
\hline Garrigues $\times$ Tuono & 50 & 39 & 11 & 37.50 & 12.50 & 0.240 & 0.624 \\
\hline Atocha $\times$ Genco & 84 & 56 & 28 & 63.00 & 21.00 & 3.111 & 0.078 \\
\hline Atocha $\times$ Tuono & 21 & 18 & 3 & 15.75 & 5.25 & 1.285 & 0.257 \\
\hline Genco $\times$ Garrigues & 16 & 13 & 3 & 12.00 & 4.00 & - & - \\
\hline Wawona $\times$ Garrigues & 54 & 37 & 17 & 40.50 & 13.50 & 1.210 & 0.271 \\
\hline Genco $\times$ Tuono & 10 & 9 & 1 & 7.50 & 2.50 & - & - \\
\hline Tuono $\times$ Genco & 44 & 35 & 9 & 33.00 & 11.00 & 0.485 & 0.486 \\
\hline Total $\mathrm{Ht} \times \mathrm{Ht}$ & 312 & 233 & 79 & 234.00 & 78.00 & 0.017 & 0.896 \\
\hline
\end{tabular}

kernels. When the other parent is heterozygous, we must expect that only 50 per cent of the individuals of the progeny will produce sweet kernels. Finally, the use of two bitter cultivars would necessarily produce 100 per cent of progeny with bitter kernels, and thus this type of cross is always inadvisable.

\section{Conclusions}

The results obtained allow us to conclude that the inheritance of kernel flavour in almond is determined by just one gene with two alleles, ' $S$ ' dominant, responsible for sweet flavour, and ' $s$ ' recessive, responsible for bitter flavour.

Among the cultivars used in this breeding programme, Garrigues, Atocha, Genco, Tuono and Wawona are heterozygous for this trait; Ramillete, Peraleja, Del Cid, Ferragnès, Mono, Primorskii and Titan are sweet homozygous.
Slighty bitter kernel-producing trees are heterozygous forms in which, occasionally and in very small proportion, the system of total dominance can be altered to express the bitter flavour in reduced form.

Due to the dominant characteristic of the sweet flavour, the use of bitter cultivars in combination with sweet homozygous is proposed for programmes of breeding by cross, when the former have some outstanding characteristic that is to be transmitted to the progeny because 100 per cent of the latter will produce sweet kernels.

\section{References}

BARbera, G., DI MARCO, L., FATTA DEL BosCO, G. AND INGLESE, P. 1987. Behaviour of 26 almond cultivars growing under rainfed and semiarid conditions in Sicily. 7 Colloque GREMPA. Reus, June 1987, pp. 17-32. 
CHANDLER, w. H. 1957. Deciduous Orchards. Lea and Febiger. Philadelphia.

EL GHARBI, A. 1981. Résultats préliminaires des croisements intervariétaux d'amandier réalisés en Tunisie. Opt. Méd. Serie Études, 81/I, 23-35.

FREHNER, M., SCALET, M. AND CONN, E. E. 1990. Pattern of the cyanide-potential in developing fruits. Plant Physiol., 94, 28-34.

GODINI, A., FERrARA, E. AND REINA, A. 1979. Composizione chimica e caratteri estetici ed organolettici dei semi di una vasta popolazione di cultivar di mandorlo pugliesi. In: Convegno Nazionale: Il Miglioramento della Coltura del Mandorlo e del Nocciolo. Aspetti Genetici e Tecnici. Messina e Siracusa, 29 e 30/11 1979, pp. 331-339.

GRASSELLY, CH. AND CROSSA-RAYNAUD, P. 1983. Mejora genética. In: Grasselly Ch. and Crossa-Raynaud, P. (eds) El Almendro. Ediciones Mundi-Prensa, Madrid, pp. 165-207.

HEPPNER, J. 1923. The factor for bitterness in the sweet almond. Genetics, 8, 390-392.

HEPPNER, J. 1926. Further evidence on the factor for bitterness in the sweet almond. Genetics, 11, 605-606.

KESTER, D. E. AND ASAY, R. N. 1975. Almonds. In: Janick, J. and Moore, J. N. (eds) Advances in Fruit Breeding. Purdue University Press, West Lafayette, IN, pp. 387-419.
MCCARTY, C. D., LESLIE, J. W. AND FROST, H. B. 1952. BitternesS of kernels of almond $\times$ peach hybrids and their parents. Proc. Am. Soc. Hort. Sci., 59, 254-258.

SPIEGEL-ROY, P. 1979. Genetics and breeding of almond and grape. Mono. Genet. Agr., 4, 275-293.

SPIEGEL-ROY, P. AND KOCHBA, J. 1974. The inheritance of bitter and double kernel characters in the almond. Z. Pflanzenzuchtg., 71, 319-329.

SPIEGEL-ROY, P. AND KOCHBA, J. 1977. Sull'hereditarietà di alcuni caratteri dei frutti di mandorlo. 3 Colloque GREMPA. Bari, October 1977, pp. 163-179.

SPIEGEL-ROY, P. AND KOCHBA, J. 1981. Inheritance of nut and kernel traits in almond. Euphytica, 30, 161-174.

vARGAS, F. J. AND ROMERO, M. A. 1988. Mejora de variedades de almendro en Cataluña. Actas III Con. SECH. Tenerife 1988 1, 94 (Abstract).

VARGAS, F. J., ROMERO, M. A., ROVIRA, M. AND GIRONA, J. 1983. Amélioration de l'amandier par croisement de variétés. Résultats préliminaires à Tarragone (Espagne). Opt. Méd. Serie Études, 1, 101-122.

woodroof, J. G. 1967. Tree Nuts: Production, Processing, Products, Vol. I. AVI Co., Westport, CT. 